TPBIO (Jurnal Pendidikan Biologi)
Vol. 5, No. I, April 2020, 64 - 72//e-ISSN 2540-802X
http://jurnal.stkippersada.ac.id/jurnal/index.php/JBIO/index

\title{
Tumbuhan obat berpotensi imunomodulator di suku anak dalam bendar bengkulu
}

A) Check for updates

\section{Fitria Lestari*, Ivoni Susanti}

Pendidikan Biologi, STKIP PGRI Lubuklinggau, J1.. Mayor Toha Kelurahan Air Kuti, Lubuklinggau (3I626), SUM-SEL, Indonesia

Korespondensi penulis: Fitrinq@gmail.com

Informasi artikel

Riwayat artikel:

Dikirim I0 Januari 2020

Direvisi 13 Februari 2020

Diterima 26 Maret 2020

Dipublikasi 07 April 2020

\section{Kata kunci:}

Imunomodulator, suku anak dalam bendar bengkulu, tumbuhan obat

\section{ABSTRAK}

Infeksi merupakan penyakit pembunuh kedua setelah kardiovaskular yang disebabkan oleh virus, bakteri, protozoa, cacing, dan jamur parasitik yang masuk ke dalam atau permukaan tubuh, sehingga hal inilah yang menjadi alasan pentingnya keberadaan imun di dalam tubuh. Bahan yang dapat memodulasi sistem imun tubuh dikenal dengan imunomodulator. Umumnya masyarakat menggunakan obat sintetis untuk mengembalikan ketidakseimbangan imun, namun penggunaan dalam jangka panjang dampak berdampak buruk bagi tubuh, seperti kerusakan ginjal, hati, dan lainnya. oleh karena itu, salah satu solusi yang diberikan dengan menggunakan tumbuhan obat seperti yang masih dipertahankan oleh Suku Anak Dalam Bendar Bengkulu. Namun, keberadaan tumbuhan ini masih belum didata, sehingga perlu dilakukan tindak lanjut agar dapat diketahui oleh masyarakat umum. Metode yang digunakan adalah eksplorasi yang dimulai dari observasi, wawancara dengan kepala suku serta masyarakat sekitar, dan dokumentasi serta identifikasi dengan menggunakan beberapa referensi yang relevan. Hasil penelitian menunjukkan bahwa terdapat 40 jenis tumbuhan obat berpotensi imunomodulator.
Keywords:

Imunomodulator, suku anak dalam bendar bengkulu, medicinal plants

\section{ABSTRACT}

The immunomodulator of plant medicine on suku anak dalam bendar bengkulu. Infection is the second most deadly disease after cardiovascular caused by viruses, bacteria, protozoa, worms and parasite fungi that come inside or surface of the body. It may cause the urgency of immune system in the body. The substance which can modulate immune system is called immunomodulator. Generally people use synthetic medicine to restore immunity damage. However, the long-term use may negatively affect the body, such as causing kidney, heart and other organs damage. Therefore, one of the solutions is by applying medicinal plants like was done by Suku Anak Dalam Bendar Bengkulu. However, the existence of the plants has not recorded yet. Therefore, it needs a further action to inform larger people. The method of the research was through exploration by doing some techniques, such as, observation, interview to the chief of the tribe and surrounding people, and documentation as well as identification by using some relevant references. The result presents there are 40 plant species which are potentially as immunomodulator.

(C) 2020 Lestari \& Susanti This is an open access article under the CC-BY-SA license

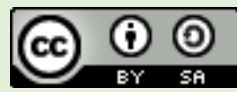

Sitasi: Lestari, F., \& Susanti, I. (2020). Tumbuhan obat berpotensi imunomodulator di suku anak dalam bendar bengkulu. JPBIO (Jurnal Pendidikan Biologi), 5(I), 64-72. DOI: I0.31932/jpbio.v5iI.59I 


\section{PENDAHULUAN}

Penyakit yang disebabkan oleh infeksi mikroba, seperti virus, bakteri, protozoa, cacing, dan jamur parasitik adalah penyebab kematian kedua didunia setelah kardiovaskular yang menandakan bahwa keberadaan imunitas sangatlah penting sebagai pertahanan tubuh (WHO, 20I4). Jika terjadi pengurangan jumlah dan fungsi sel imun, maka penyakit infeksi oleh mikroorganisme akan dengan mudah timbul (Joyce \& Swain, 2008). Oleh karena itu perlu sebuah substansi dalam tubuh. Substansi yang dapat membantu memperbaiki fungsi sistem imun dikenal sebagai imunomodulator (Masihi, 200I; Kayser et al., 2003). Mekanisme imunomodulator meliputi mengembalikan fungsi imun yang terganggu (imunorestorasi), memperbaiki fungsi sistem imun (imunostimulasi) dan menekan respons imun (imunosupresi).

Umumnya, pengobatan penyakit infeksi menggunakan obat-obat sintetis, seperti ketoprofen, aspirin, azatioprin, sitoksan, isoprinosin, levamsiol, arginin dan lain sebagainya. Namun, penggunaan obat sintetis dalam jangka waktu yang panjang dapat mengakibatkan efek negatif, seperti penurunan kadar trombosit, depresi pernapasan, uritakaria, toksik terhadap hati, dan gangguan saluran pencernaan. Oleh karena itu, salah satu cara untuk mengurangi efek dari penggunaan obat sintetis, yaitu menggunakan tumbuhan obat yang berpotensi sebagai imunomodulator. Kelebihan dari penggunaan tumbuhan sebagai obat, yaitu mudah didapatkan, harga murah, dan efek samping yang ditimbulkan sedikit. Menurut Pranata (20I4), penggunaan tumbuhan sebagai obat dikarenakan mudah ditemukan, dan mudah dikembangbiakkan Salah satu suku yang ada di Kabupaten Musi Rawas yang masih menggunakan tumbuhan sebagai obat adalah Suku Anak Dalam Bendar Bengkulu.

Hasil wawancara dengan kepala suku Anak Dalam Bendar Bengkulu diketahui bahwa suku ini masih menggunakan tumbuhan sebagai obat penyakit infeksi, seperti: I) daun, akar, dan bunga bougenvile sebagai obat keputihan; 2) daun tapak dara sebagai obat leukimia; 3) daun dan bunga alamanda digunakan untuk penawar racun dan obat malaria dan lainnya. Menurut Jauhari et al. (20I2) perilaku Suku Anak Dalam diturunkan dari nenek moyangnya yang sangat tergantung dengan alam dalam meramunya. Namun, keberadaan tumbuhan yang digunakan sebagai obat oleh suku ini belum tercatat dan diidentifikasi dengan baik. Hal ini terbukti dengan belum ditemukannya referensi yang membahas tentang tumbuhan obat oleh suku ini secara online maupun buku.

Dokumentasi mengenai pengetahuan tradisional tumbuhan sangat penting karena dapat diturunkan ke generasi selanjutnya (Hidayat \& Hardiansyah, 2012). Oleh karena itu, penelitian ini diharapkan menjadi data awal keberadaan tumbuhan obat yang terdiri atas: jenis, bagian yang digunakan, dan cara pengolahan yang digunakan oleh suku Anak Dalam Bendar Bengkulu khususnya sebagai imunomodulator.

\section{METODE PENELITIAN}

\section{Rancangan Penelitian}

Jenis penelitian ini adalah kualitatif. Penelitian kualitatif lebih bersifat deskriptif yaitu data yang terkumpul berbentuk kata-kata atau gambar sehingga tidak menekankan pada angka dan lebih menekankan pada proses daripada produk (Sugiyono, 2012). Obyek dalam penelitian ini adalah semua tumbuhan yang berpotensi sebagai imunomodulator di Suku Anak Dalam Bendar Bengkulu. Masyarakat yang menjadi informan dipilih dengan cara purposive sampling dan snowball sampling. Informan yang dianggap ahli dalam tumbuhan obat yaitu seperti tokoh adat, tokoh masyarakat, penjual jamu, dukun dan tukang urut serta masyarakat yang mengetahui tentang tumbuhan obat.

\section{Instrumen Penelitian}

Instrumen yang digunakan dalam penelitian, adalah I) lembar observasi, yang digunakan pada saat melakukan observasi di lapangan; dan 2) lembar wawancara, yang berfungsi sebagai salah satu instrumen untuk mengumpulkan data penelitian di lapangan.

\section{Prosedur Penelitian}

Prosedur penelitian dimulai dari tahap observasi dan wawancara untuk menggali informasi dari ketua dan masyarakat Suku Anak Dalam Bendar Bengkulu tentang penggunaan tumbuhan obat berpotensi imunomodulator menggunakan lembar observasi dan lembar wawancara. Setelah itu, dilakukan dokumentasi terhadap tumbuhan sebagai bukti telah melakukan penelitian. Tahap selanjutnya melakukan identifikasi dengan menggunakan buku referensi tumbuhan obat seperti buku flora oleh Steenis (2013) dan morfologi tumbuhan oleh Tjitrosoepomo (20II). Identifikasi tumbuhan menggunakan lembar identifikasi. Setelah dilakukan identifikasi, kemudian tumbuhan obat direkapitulasi jumlahnya. 


\section{Teknik Analisis Data}

Analisis data menggunakan teknik analisis deskriptif kualitatif. Analisis deskriptif kualitatif dilakukan dengan mengidentifikasi jenis, bagian yang dimanfaatkan, serta cara pengolahan tumbuhan obat oleh Suku Anak Dalam Bendar Bengkulu Kabupaten Musi Rawas. Perhitungan analisis deskriptif kualitatif dilakukan dengan menggunakan rumus persentase.

\section{HASIL PENELITIAN}

Berdasarkan hasil observasi dan wawancara dengan kepala suku dan masyarakat diketahui bahwa terdapat 40 jenis dari 30 famili tumbuhan obat berpotensi imunomodulator (Lampiran I). Setelah dilakukan observasi dan wawancara, tumbuhan yang didapat kemudian dilakukan identifikasi yang terdiri dari nama latin dan famili dari tumbuhan obat imunomodulator yang ditemukan. Hasil penelitian juga menunjukkan bahwa terdapat jenis tumbuhan dari suku Anak Dalam Bendar Bengkulu yang berbeda dari suku lain, seperti: Bangle hantu, jelai, dan terong susu kerbau.

Tabel I. Bagian yang digunakan tumbuhan obat imunomodulator

\begin{tabular}{llcc}
\hline No & Bagian yang digunakan & Jumlah & Persentase (\%) \\
\hline I & Daun & 26 & 35,60 \\
\hline 2 & Akar & I0 & 13,70 \\
\hline 3 & Batang & 4 & 5,48 \\
\hline 4 & Bunga & 7 & 9,58 \\
\hline 5 & Kulit & 2 & 2,72 \\
\hline 6 & Biji & 8 & 10,95 \\
\hline 7 & Rimpang & 3 & $4,1 \mathrm{I}$ \\
\hline 8 & Buah & $\mathrm{I} 0$ & $\mathrm{I3,70}$ \\
\hline 9 & Umbi & 2 & $2,7 \mathrm{I}$ \\
\hline 10 & Getah & $\mathrm{I}$ & 1,37 \\
\hline & Jumlah & 73 & $\mathbf{1 0 0}$ \\
\hline
\end{tabular}

Bagian tumbuhan yang digunakan untuk imunomodulator sebanyak IO bagian, yaitu: daun, akar, batang, bunga, kulit, biji, rimpang, buah, umbi, dan getah. Bagian yang paling banyak digunakan adalah daun, sedangkan yang paling sedikit adalah getah (Tabel I).

Tabel 2. Persentase cara pengolahan tumbuhan obat imunomodulator

\begin{tabular}{llcc}
\hline No & Cara pengolahan & Jumlah & Persentase (\%) \\
\hline $\mathrm{I}$ & Direbus & 28 & 34.56 \\
\hline 2 & Diseduh & 3 & 3,70 \\
\hline 3 & Diperas & 6 & $7,4 \mathrm{I}$ \\
\hline 4 & Ditempel & $\mathrm{I} 4$ & $\mathrm{I} 7,28$ \\
\hline 5 & Tanpa diramu & 7 & 8,64 \\
\hline 6 & Diasapkan/dipanggang & 7 & 8,64 \\
\hline 7 & Dihaluskan & $\mathrm{I} 2$ & $\mathrm{I} 4,8 \mathrm{I}$ \\
\hline 8 & Diparut & 3 & 3,70 \\
\hline 9 & Ditetes & $\mathrm{I}$ & $\mathrm{I}, 23$ \\
\hline & Jumlah & $\mathbf{8 I}$ & $\mathbf{I 0 0}$ \\
\hline
\end{tabular}

Cara pengolahan tumbuhan obat berpotensi imunomodulator berdasarkan hasil observasi dan wawancara dikatahu terdapat 9 cara, yaitu: direbus, diseduh, diperas, ditempel, tanpa diramu, diasapkan atau dipanggang, diaprut, dihaluskan, dan ditetes (Tabel 2).

\section{PEMBAHASAN}

Berdasarkan Lampiran I. diketahui bahwa terdapat 40 jenis dari 30 famili tumbuhan yang berpotensi sebagai imunomodulator. Famili terbanyak yang ditemukan adalah Zingiberaceae sedangkan famil kedua terbanyak adalah Euphorbiaceae dikarenakan mudah tumbuh, mudah diperoleh dan dapat mengobati berbagai macam penyakit. Banyaknya penggunaan obat dari famili Eupohorbiaceae dikarenakan mudah ditemukan, mudah dol10.31932/jpbio.v5iI.59I Lestari \& Susanti jomailipbio@om 
dibudidayakan, dan telah dilakukan secara turun-temurun (Harmida et al., 20II; Kinho, 20II)). Selain itu, Famili Zingiberaceae jenis tumbuhan temu-temuan dengan ciri khasnya yang mudah tumbuh, batang semu, tipe daun lengkap dan daun tunggal, dan ditemukan di kawasan tropis, terutama Indo-Malaya dengan ciri mengandung minyak yang menguap dan beraroma khas dari rimpangnya (Auliani et al., 20I4; Hartanto et al., 20I4; Washika, 2016).

Hasil anaisis deskriptif pada Tabel I. diketahui bahwa bagian yang paling banyak digunakan adalah daun, sedangkan yang paling sedikit adalah getah. Bagian daun mudah diolah karena tekstur yang lembut karena memiliki kandungan air yang tinggi, mudah tumbuh kembali, dan berperan dalam proses fotosintesis (Setyowati, 20I0; Tjitrosoepomo, 20II; Kaunang \& Semuel, 2017). Sel-sel dalam jaringan daun menghasilkan metabolik sekunder seperti tanin, alkaloid, minyak atsiri yang berpotensi untuk mengobati penyakit (Kartika, 2015). Organ daun lebih mudah digunakan untuk mengambil sari atau khasiat yang dimiliki tumbuhan (Jalius \& Muswita, 2013).

Uji kandungan fitokimia beberapa jenis tumbuhan lokal yang sering dimanfaatkan sebagai bahan baku obat di pulau Lombok menggunakan bagian daun. Hasil penelitian menunjukan bahwa bagian daun mengandung senyawa metabolik sekunder yang memiliki sifat antibakteri, pendenaturasi protein, seta mencegah proses pencernaan bakteri. Senyawa metabolik sekunder diantaranya flavanoid, alkaloid, steroid, tanin, saponin, antrakuinon dan terpenoid (Rohyani et al., 2015).

Berdasarkan Tabel 2. diketahui bahwa cara pengolahan yang paling banyak adalah dengan cara direbus. Tujuan merebus tumbuhan obat adalah untuk memindahkan zat yang ada didalam tumbuhan ke dalam larutan air, kemudian diminum dan akan bereaksi dengan cepat bila diminum untuk pengobatan (Mahendra, 2006; Gunadi et al., 2017). Pengolahan dengan cara direbus juga mengurangi rasa hambar dan pahit, serta lebih steril dikarenakan dapat membunuh kuman ataupun bakteri yang patogen (Novianti, 20I4). Cara perebusan dipercaya masyarakat dapat membunuh kuman yang ada pada tumbuhan, lebih aman dan senyawa kandungan yang ada pada tumbuhan lebih banyak keluar.

Akitivitas antioksidan akan semakin rendah jika waktu perebusan juga lama (Wicaksono, 2015). Hal ini didukung oleh penelitian Oematan (2015) bahwa pada suhu $60^{\circ} \mathrm{C}$ akan menyebabkan sel pada daun terdegradasi yang mengakibatkan senyawa didalamnya kelur dan larut dalam air sehingga aktivitas antioksida menurun (Oematan, 2015).

\section{SIMPULAN}

Berdasarkan hasil penelitian dapat disimpulkan bahwa banyak terdapat tumbuhan obat yang berpotensi imunomodulator yang masih diterapkan oleh Suku Anak Dalam Bendar Bengkulu. Hasil penelitian ini dapat menjadi alternatif untuk meminimalisir penggunaan dan dampak jangka panjang dari obat kimia yang ada dipasaran.

\section{UCAPAN TERIMAKASIH}

Ucapan terimakasih peneliti sampaikan kepada Kemenristekdikti yang telah memberikan kepercayaan kepada peneliti sebagai penerima hibah Penelitian Dosen Pemula (PDP) untuk anggaran 2018.

\section{REFERENSI}

Auliani, A., Fitmawati, \& Sofiyanti, N. (20I4). Studi etnobotani famili zingiberaceae dalam kehidupan masyarakat lokal di kecamatan siak hulu, kabupaten kampar. Jurnal JOM FMIPA, I(2), 526-533. https://jom.unri.ac.id/index.php/JOMFMIPA/article/view/3987

Gunadi, D., Oramahi, H.A., \& Tavita, G.E. (2017). Studi tumbuhan obat pada etnis dayak di desa geranting kecamatan monterado kabupaten bengkayang. Jurnal Hutan Lestari, 5(2), 425-436. http://jurnal.untan.ac.id/index.php/jmfkh/article/view/20089

Hartanto, S., Fitmawati, \& Sofiyanti, N. (20I4). Studi etnobotani famili zingiberaceae dalam kehidupan masyarakat lokal di kecamatan pangan kabupaten kuantan singingi riau. Jurnal of Biology \& Biology Education, 6(2), I22-I32. DOI: I0.I5294/biosaintifika.v6i2.3I05

Harmida., Sarno, \& Yuni, V.F. (20II). Studi etnofitomedika di desa lawang agung kecamatan mulak ulu kabupaten lahat sumatera selatan. jurusan biologi fmipa, universitas sriwijaya, sumatera selatan. Jurnal Penelitian Sains, I4(I), 42-46. http://ejurnal.mipa.unsri.ac.id/index.php/jps/article/view/I26

Hidayat, D., \& Hardiansyah, G. (2012). Studi keanekaragaman jenis tumbuhan obat di kawasan iuphhk pt. sari bumi kusuma camp tontang kabupaten sintang. Journal Biology Science, 8(2), 6I-68. http://repository.polnep.ac.id/xmlui/handle/I23456789/75 
Jalius, \& Muswita. (2013). Eksplorasi pengetahuan lokal tentang tumbuhan obat di suku batin jambi. Biospesies. 6(I), 28-37. https://online-journal.unja.ac.id/index.php/biospecies/article/view/688

Jauhari, Arislan, S., Indratno, \& Diana, S. (20I2). Jejak peradaban suku anak dalam. Bangko: Lembaga Swadaya Masyarakat Kelompok Suku Anak Dalam. Jambi: Lembaga Swadaya Masyarakat, Kelompok Peduli Suku Anak Dalam (LSM Kopsad),

Joyce, B., \& Swain. (2008). Prinsip-prinsip sains untuk keperawatan. Jakarta: Erlangga.

Kartika, T. (2015). Inventarisasi jenis-jenis tumbuhan berkhasiat obat di desa tanjung baru petai kecamatan tanjung batu kabupaten ogan ilir (oi) provinsi sumatera selatan. Sainmatika, I2(I). https://jurnal.univpgri-palembang.ac.id/index.php/sainmatika/article/view/436

Kaunang, N.E., \& Semuel, M.Y. (2017). Botanical and phytochemical constituents of veral medicinal plants from mount klabat north minahasa. Jurnal of Medicinal Plants Studies, 5(2), 29-35 http://www.plantsjournal.com/archives/2017/vo15issue2/PartA/5-I-68-348.pdf

Kayser, O., Masihi, K.N., \& Kiderlen, F.K. (2003). Natural products and synthetic compounds as immunomodulators. Journal Expret Rev Anti-infect Ther, I(2), 3I-35. DOI: I0.1586/147872I0.1.2.319

Kinho. (2011). Tumbuhan obat tradisional di sulawesi utara jilid II. Manado: Balai Penelitian Kehutanan Manado.

Masihi, K.N. (200I). Fighting infection using immunomodulatory agents. Journal Exp Opin Biol Ther, I(4), 64-73. DOI: I0.15I7/I47I2598.I.4.64I

Mahendra, B. (2006). I3 jenis tanaman obat ampuh. Jakarta: Penebar Swadaya.

Novianti. (2014). Kajian etnofarmakognosi dan etnofarmakologi penggunaan tumbuhan obat di desa cisangkal kecamatan cihurip kabupaten garut. Farmako Bahari, 5(2), I-I9. https://fmipa.uniga.ac.id/wpcontent/uploads/2016/04/

Oematan. (2015). Pengaruh perbedaan suhu dan waktu ekstraksi terhadap kandungan tanin pada ekstrak daun jambu mete (anacurdium occidentale). Jurnal Ilmiah Mahasiswa Universitas Surabaya, 4(2), I-I2. http://journal.ubaya.ac.id/index.php/jimus/article/view/208I

Pranata, S. (20I4). Herbal toga (tanaman obat keluarga). Yogyakarta: Aksara Sukses.

Rohyani, I.S., Aryanti, E., \& Suripto. (2015). Kandungan fitokimia beberapa jenis tumbuhan lokal yang sering dimanfaatkan sebagai bahan baku obat di pulau lombok. Jurnal Pros Sem Nas Masy Biodiv Indon, I(I), 388-39I. DOI: I0.I3057/psnmbi/m0I0237

Setyowati, F.M. (2010). Etnofarmakologi dan pemakaian tanaman obat suku dayak tunjung di kalimantan timur. $\begin{array}{llll}\text { Jurnal Media } \quad \text { Litbang } & \text { Kesehatan, } & \text { I04-II2 }\end{array}$ https://media.neliti.com/media/publications/I53674-ID-etnofarmakologi-dan-pemakaian-tanamanob.pdf

Steenis, C.G.G.J.V. (2013). Flora untuk sekolah di indonesia. Jakarta: Balai Pustaka.

Sugiyono. (2012). Metode penelitian kuantitatif, kualitatif dan $r \&$ d. Bandung: Alfabeta.

Tjitrosoepomo. (201 I). Morfologi tumbuhan. Yogyakarta: Gadjah Mada University Press.

Washika. (2016). Tumbuhan zingibereaceae sebagai obat-obatan. Jurmal Serambi Saintia, 4(I), 35-43. http://ojs.serambimekkah.ac.id/index.php/serambi-saintia/article/viewFile/II4/II I

Wicaksono. (2015). Pengaruh karagenan dan lama perebusan daun sirsak terhadap mutu dan karakteristik jelly drink daun sirsak. Jurnal Pangan dan Agroindustri, 3(I), 28I-29I. https://jpa.ub.ac.id/index.php/jpa/article/view/I34

World Health Organization. (2004). The global burden of disease: 2004 update. Switzerland. 
Lampiran I. Jenis-jenis tumbuhan obat imunomodulator di suku anak dalam bendar bengkulu

\begin{tabular}{|c|c|c|c|c|c|c|c|}
\hline \multirow[b]{2}{*}{ No } & \multirow{2}{*}{$\begin{array}{c}\text { Nama } \\
\text { Spesies/ } \\
\text { Nama Lokal }\end{array}$} & \multirow[b]{2}{*}{ Famili } & \multirow[b]{2}{*}{ Nama Latin } & \multirow{2}{*}{$\begin{array}{l}\text { Bagian } \\
\text { yang di } \\
\text { gunakan }\end{array}$} & \multirow[b]{2}{*}{$\begin{array}{c}\text { Cara } \\
\text { Pengolahan }\end{array}$} & \multicolumn{2}{|c|}{ Kegunaan } \\
\hline & & & & & & $\begin{array}{c}\text { Menurut } \\
\text { Masyarakat }\end{array}$ & $\begin{array}{l}\text { Menurut } \\
\text { Referensi }\end{array}$ \\
\hline $\mathrm{I}$ & Alamanda & Apocynaceae & $\begin{array}{l}\text { Allamanda } \\
\text { cathartica }\end{array}$ & $\begin{array}{l}\text { Daun, } \\
\text { bunga }\end{array}$ & Direbus & $\begin{array}{l}\text { Luka, } \\
\text { malaria. }\end{array}$ & $\begin{array}{l}\text { Penawar racun, } \\
\text { disentri, dan } \\
\text { malaria (Hidayat } \\
\text { \& Napitupulu } \\
\text { 2015:29) }\end{array}$ \\
\hline 2 & $\begin{array}{l}\text { Alpukat/ } \\
\text { Pokad }\end{array}$ & Lauraceae & $\begin{array}{l}\text { Persea } \\
\text { americana }\end{array}$ & $\begin{array}{l}\text { Daun, } \\
\text { buah,biji }\end{array}$ & Dihaluskan & Darah tinggi & $\begin{array}{l}\text { Darah tinggi, batu } \\
\text { ginjal, kencing } \\
\text { batu, kencing } \\
\text { manis (Subagja, } \\
\text { 20I3: } 37 \text { ) }\end{array}$ \\
\hline 3 & Bandotan & Asteraceae & $\begin{array}{l}\text { Ageratum } \\
\text { conyzoides }\end{array}$ & $\begin{array}{l}\text { Akar, } \\
\text { daun }\end{array}$ & $\begin{array}{l}\text { Direbus, } \\
\text { Ditempel, }\end{array}$ & $\begin{array}{l}\text { Disentri, } \\
\text { luka, diare. }\end{array}$ & $\begin{array}{l}\text { Pendarahan luka } \\
\text { (Naesin, 2008: } \\
\text { 2I) }\end{array}$ \\
\hline 4 & $\begin{array}{l}\text { Bangle/ } \\
\text { Gemelai }\end{array}$ & Zingiberaceae & $\begin{array}{l}\text { Zingiber } \\
\text { cassumunar }\end{array}$ & Rimpang & $\begin{array}{l}\text { Direbus, } \\
\text { Diperas, } \\
\text { Ditempel, } \\
\text { Dihaluskan }\end{array}$ & $\begin{array}{l}\text { Demam, } \\
\text { sariawan }\end{array}$ & $\begin{array}{l}\text { Sakit kepala, } \\
\text { demam, masuk } \\
\text { angin, obat mata. } \\
\text { (Subagja, 2013: } \\
46 \text { ) }\end{array}$ \\
\hline 5 & $\begin{array}{l}\text { Bangle } \\
\text { hantu/ } \\
\text { Gemelai atu }\end{array}$ & Zingiberaceae & $\begin{array}{l}\text { Zingiber } \\
\text { ottensii }\end{array}$ & $\begin{array}{l}\text { Rimpang, } \\
\text { daun }\end{array}$ & $\begin{array}{l}\text { Dihaluskan, } \\
\text { Direbus, } \\
\text { Ditempel }\end{array}$ & $\begin{array}{l}\text { Demam, } \\
\text { batuk }\end{array}$ & $\begin{array}{l}\text { Gatal-gatal, sakit } \\
\text { pinggang, demam } \\
\text { (Hidayat \& } \\
\text { Napitupulu 20I5: } \\
46 \text { ) }\end{array}$ \\
\hline 6 & Bayam duri & Amaranthaceae & $\begin{array}{l}\text { Amaranthus } \\
\text { spinosus }\end{array}$ & $\begin{array}{l}\text { Seluruh } \\
\text { bagian }\end{array}$ & $\begin{array}{l}\text { Ditempel, } \\
\text { Dihaluskan }\end{array}$ & $\begin{array}{l}\text { Sakit gigi, } \\
\text { bisul }\end{array}$ & $\begin{array}{l}\text { Disentri, demam, } \\
\text { kencing nanah, } \\
\text { keputihan, } \\
\text { penambah darah. } \\
\text { Subagja, 20I3: 64) }\end{array}$ \\
\hline 7 & $\begin{array}{l}\text { Belimbing } \\
\text { wuluh }\end{array}$ & Oxalidaceae & $\begin{array}{l}\text { Averhoa } \\
\text { bilimbi }\end{array}$ & $\begin{array}{l}\text { Buah, } \\
\text { bunga, } \\
\text { daun }\end{array}$ & $\begin{array}{l}\text { Direbus, } \\
\text { Ditempel, } \\
\text { Tanpa } \\
\text { Diramu, } \\
\text { Dihaluskan, } \\
\text { Diparut } \\
\end{array}$ & $\begin{array}{l}\text { Sariawan, } \\
\text { penurun } \\
\text { panas. }\end{array}$ & $\begin{array}{l}\text { Gondongan, } \\
\text { panu, jerawat, } \\
\text { sariawan. } \\
\text { (Hidayat \& } \\
\text { Napitupulu 20I5: } \\
54 \text { ) }\end{array}$ \\
\hline 8 & Bunga knop & Amaranthaceae & $\begin{array}{l}\text { Gomphrena } \\
\text { globosa }\end{array}$ & $\begin{array}{l}\text { Seluruh } \\
\text { bagian }\end{array}$ & Direbus & Kanker & $\begin{array}{l}\text { Asma, koreng. } \\
\text { (Hidayat \& } \\
\text { Napitupulu 20I5: } \\
75 \text { ) }\end{array}$ \\
\hline 9 & $\begin{array}{l}\text { Bunga } \\
\text { pukul empat }\end{array}$ & Nyctaginaceae & Mirabilis jalava & $\begin{array}{l}\text { Akar, } \\
\text { daun, biji }\end{array}$ & $\begin{array}{l}\text { Ditempel, } \\
\text { Diasapkan/ } \\
\text { Dipanggang, } \\
\text { Dihaluskan }\end{array}$ & $\begin{array}{l}\text { Komedoo, } \\
\text { jerawat. }\end{array}$ & $\begin{array}{l}\text { Radang amandel, } \\
\text { bisul, jerawat. } \\
\text { (Hidayat \& } \\
\text { Napitupulu 20I5: } \\
\text { 8I) }\end{array}$ \\
\hline I0 & $\begin{array}{l}\text { Bunga tahi } \\
\text { kotok }\end{array}$ & Asteraceae & Tagetes erecta & $\begin{array}{l}\text { Daun, } \\
\text { bunga }\end{array}$ & $\begin{array}{l}\text { Direbus, } \\
\text { Ditempel, } \\
\text { Diasapkan/ } \\
\text { Dipanggang }\end{array}$ & $\begin{array}{l}\text { Gondongan, } \\
\text { sakit gigi. }\end{array}$ & $\begin{array}{l}\text { Radang kulit, } \\
\text { batuk, sakit gigi, } \\
\text { gondongan. } \\
\text { (Hidayat \& } \\
\text { Napitupulu 20I5: } \\
83 \text { ) }\end{array}$ \\
\hline II & Bougenvil & Nyctaginaceae & $\begin{array}{l}\text { Bougainvillea } \\
\text { spectabilis }\end{array}$ & $\begin{array}{l}\text { akar, } \\
\text { bunga }\end{array}$ & Direbus & Batuk & $\begin{array}{l}\text { Keputihan, bisul, } \\
\text { hepatitis. } \\
\text { (Hidayat \& }\end{array}$ \\
\hline
\end{tabular}




\begin{tabular}{|c|c|c|c|c|c|c|c|}
\hline & & & & & & & $\begin{array}{l}\text { Napitupulu 20I5: } \\
73 \text { ) }\end{array}$ \\
\hline $\mathrm{I} 2$ & $\begin{array}{l}\text { Cabai } \\
\text { rawit/ } \\
\text { Cabe rawet }\end{array}$ & Solanaceae & $\begin{array}{l}\text { Capsicum } \\
\text { annum }\end{array}$ & Buah & $\begin{array}{l}\text { Diasapkan / } \\
\text { Dipanggang }\end{array}$ & $\begin{array}{l}\text { Rematik, } \\
\text { menurunkan } \\
\text { berat badan. }\end{array}$ & $\begin{array}{l}\text { Mempercepat } \\
\text { metabolisme } \\
\text { tubuh, } \\
\text { meringankan rasa } \\
\text { nyeri, } \\
\text { menurunkan berat } \\
\text { badan, dan darah } \\
\text { tinggi. (Hidayat \& } \\
\text { Napitupulu 20I5: } \\
86 \text { ) }\end{array}$ \\
\hline $\mathrm{I3}$ & Daun salam & Myartaceae & $\begin{array}{l}\text { Syzigium } \\
\text { polynathum }\end{array}$ & Daun & $\begin{array}{l}\text { Direbus, } \\
\text { Dihaluskan }\end{array}$ & $\begin{array}{l}\text { Diabetes, } \\
\text { asam urrat, } \\
\text { hipertensi. }\end{array}$ & $\begin{array}{l}\text { Diare, kencing } \\
\text { manis, magh. } \\
\text { (Hidayat \& } \\
\text { Napitupulu 20I5: } \\
\text { 36) }\end{array}$ \\
\hline $\mathrm{I} 4$ & Duku & Meliaceae & $\begin{array}{l}\text { Lansium } \\
\text { domesticum }\end{array}$ & $\mathrm{Biji}$ & $\begin{array}{l}\text { Tanpa } \\
\text { Diramu }\end{array}$ & $\begin{array}{l}\text { Malaria, } \\
\text { demam. }\end{array}$ & $\begin{array}{l}\text { Cacing, mencret. } \\
\text { (Mayanti, 2009: } \\
\text { I53). }\end{array}$ \\
\hline I5 & $\begin{array}{l}\text { Jambu biji/ } \\
\text { Jambu } \\
\text { terong }\end{array}$ & Myartaceae & $\begin{array}{l}\text { Psidium } \\
\text { guajava }\end{array}$ & Daun & $\begin{array}{l}\text { Direbus, } \\
\text { Tanpa } \\
\text { Diramu, }\end{array}$ & $\begin{array}{l}\text { Diare, } \\
\text { demam } \\
\text { berdarah. }\end{array}$ & $\begin{array}{l}\text { Diare (Murtie, } \\
\text { 20I3:14) }\end{array}$ \\
\hline 16 & $\begin{array}{l}\text { Jali/ } \\
\text { Jelai }\end{array}$ & Poacceae & $\begin{array}{l}\text { Coix lacryma- } \\
\text { jobi }\end{array}$ & Buah, akar & Direbus & Gatal-gatal & $\begin{array}{l}\text { Kencing batu. } \\
\text { (Hidayat \& } \\
\text { Napitupulu 20I5: } \\
\text { I49) }\end{array}$ \\
\hline I7 & $\begin{array}{l}\text { Jeruk purut } \\
\text { / limaut } \\
\text { porot }\end{array}$ & Rutaceae & Citrus hystrix & $\begin{array}{l}\text { Buah, } \\
\text { daun }\end{array}$ & $\begin{array}{l}\text { Direbus, } \\
\text { Diperas }\end{array}$ & $\begin{array}{l}\text { Menurunka } \\
\mathrm{n} \text { panas }\end{array}$ & $\begin{array}{l}\text { Flu, kelelahan. } \\
\text { (Hidayat \& } \\
\text { Napitupulu 20I5: } \\
\text { I65) }\end{array}$ \\
\hline I8 & $\begin{array}{l}\text { Kembang } \\
\text { sepatu }\end{array}$ & Malvaceae & $\begin{array}{l}\text { Hibiscus } \\
\text { rosasinensis }\end{array}$ & Bunga & Direbus & $\begin{array}{l}\text { Radang } \\
\text { tenggoroka } \\
\mathrm{m}, \\
\text { menurunkan } \\
\text { panas } \\
\end{array}$ & $\begin{array}{l}\text { Gondongan } \\
\text { (Hidayat \& } \\
\text { Napitupulu 20I5: } \\
\text { 205) }\end{array}$ \\
\hline I9 & Kencur & Zingiberaceae & $\begin{array}{l}\text { Kaempferia } \\
\text { galanga }\end{array}$ & Rimpang & $\begin{array}{l}\text { Direbus, } \\
\text { Diseduh, } \\
\text { Diparut }\end{array}$ & $\begin{array}{l}\text { Keseleo, } \\
\text { bengkak, } \\
\text { meningkatk } \\
\text { an daya } \\
\text { tahan tubuh. }\end{array}$ & $\begin{array}{l}\text { Batuk terkilir, } \\
\text { penambah nafsu } \\
\text { makan. (Hidayat } \\
\& \text { Napitupulu } \\
\text { 2015: 2I5) }\end{array}$ \\
\hline 20 & Keladi tikus & Araceae & $\begin{array}{l}\text { Typhonium } \\
\text { flagelliforme }\end{array}$ & Umbi & Direbus & Kanker & $\begin{array}{l}\text { Kanker (Hidayat } \\
\text { \& Napitupulu } \\
\text { 2015: 196) }\end{array}$ \\
\hline $2 \mathrm{I}$ & $\begin{array}{l}\text { Lengkuas/ } \\
\text { Laos }\end{array}$ & Zingiberaceae & Alpinia galanga & Rimpang & $\begin{array}{l}\text { Diperas, } \\
\text { Dihaluskan }\end{array}$ & $\begin{array}{l}\text { Batuk, } \\
\text { menghangat } \\
\text { kan badan. }\end{array}$ & $\begin{array}{l}\text { Panu, menjaga } \\
\text { stamina pria. } \\
\text { (Hidayat \& } \\
\text { Napitupulu 20I5: } \\
\text { 253) }\end{array}$ \\
\hline 22 & $\begin{array}{l}\text { Lidah } \\
\text { mertua }\end{array}$ & Liliaceae & $\begin{array}{l}\text { Sansevieria } \\
\text { trifasciata }\end{array}$ & Daun & $\begin{array}{l}\text { Direbus, } \\
\text { Ditempel, } \\
\text { Diseduh }\end{array}$ & $\begin{array}{l}\text { Radang } \\
\text { kulit, diare, } \\
\text { radang usus, } \\
\text { radang } \\
\text { lambung. } \\
\end{array}$ & $\begin{array}{l}\text { Batu, diabetes. } \\
\text { (Hidayat \& } \\
\text { Napitupulu 20I5: } \\
\text { 257) }\end{array}$ \\
\hline 23 & Mangga & Anacardiaceae & $\begin{array}{l}\text { Mangifera } \\
\text { indica }\end{array}$ & $\begin{array}{l}\text { Daun, } \\
\text { buah }\end{array}$ & $\begin{array}{l}\text { Direbus, } \\
\text { Diperas, } \\
\text { Tanpa } \\
\text { Diramu }\end{array}$ & $\begin{array}{l}\text { Panas } \\
\text { dalam, } \\
\text { diare. }\end{array}$ & $\begin{array}{l}\text { Kesehatan kulit, } \\
\text { diare, darah } \\
\text { tinggi, kolestrol } \\
\text { (Nugraha 2008: } \\
43 \text { ) }\end{array}$ \\
\hline 24 & Manggis & Clusiaceae & Garcinia & Kulit, & Direbus, Ta & Kencing & Diare, dosentri, \\
\hline
\end{tabular}




\begin{tabular}{|c|c|c|c|c|c|c|c|}
\hline & & & mangostana & buah & npa Diramu & manis, & kanker. \\
\hline 25 & $\begin{array}{l}\text { Mahkota } \\
\text { dewa }\end{array}$ & Thymelaceae & $\begin{array}{l}\text { Phaletia } \\
\text { macrocarpa }\end{array}$ & $\begin{array}{l}\text { Buah, } \\
\text { daun, biji }\end{array}$ & $\begin{array}{l}\text { Diasapkan / } \\
\text { Dipanggang }\end{array}$ & $\begin{array}{l}\text { Darah } \\
\text { tinggi, } \\
\text { kanker, } \\
\text { diabetes. }\end{array}$ & $\begin{array}{l}\text { Kanker, diabetes, } \\
\text { darrah tinggi. } \\
\text { (Hidayat \& } \\
\text { Napitupulu 20I5: } \\
\text { 26I) }\end{array}$ \\
\hline 26 & Meniran & Euphorbiaceae & $\begin{array}{l}\text { Phyllanthus } \\
\text { niruri }\end{array}$ & Akar & Direbus & Hepatitis & $\begin{array}{l}\text { Luka, diare, } \\
\text { pennambah nafsu } \\
\text { makan (Hidayat } \\
\text { \& Napitupulu } \\
\text { 2015: 274) }\end{array}$ \\
\hline 27 & $\begin{array}{l}\text { Nanas } \\
\text { kerang }\end{array}$ & Rhizophoraceae & $\begin{array}{l}\text { Tradescantia } \\
\text { spathacea }\end{array}$ & Daun & $\begin{array}{l}\text { Direbus, } \\
\text { Ditempel, } \\
\text { Diasapkan / } \\
\text { Dipanggang } \\
\end{array}$ & $\begin{array}{l}\text { Tuberkulosi } \\
\text { s, muntah } \\
\text { darah. }\end{array}$ & $\begin{array}{l}\text { Batuk, luka, } \\
\text { terkilir. (Hidayat } \\
\text { \& Napitupulu } \\
\text { 2015: 288) }\end{array}$ \\
\hline 28 & $\begin{array}{l}\text { Nangka/ } \\
\text { Nake }\end{array}$ & Moraceae & $\begin{array}{l}\text { Artocarpus } \\
\text { heterophyllus }\end{array}$ & Buah, biji & $\begin{array}{l}\text { Dihaluskan, } \\
\text { Ditempel }\end{array}$ & Diare & $\begin{array}{l}\text { Jerawat, komedo, } \\
\text { penghalus kulit. } \\
\text { (Hidayat \& } \\
\text { Napitupulu 20I5: } \\
289 \text { ) }\end{array}$ \\
\hline 29 & Pacar air & Balsaminaceae & $\begin{array}{l}\text { Impatiens } \\
\text { balsamina }\end{array}$ & $\begin{array}{l}\text { Daun, } \\
\text { bunga }\end{array}$ & $\begin{array}{l}\text { Direbus, } \\
\text { Diasapkan / } \\
\text { Dipanggang }\end{array}$ & Keputihan. & $\begin{array}{l}\text { Keputihan } \\
\text { (Hidayat \& } \\
\text { Napitupulu 20I5: } \\
\text { 292) }\end{array}$ \\
\hline 30 & Pacar kuku & Lythraceae & $\begin{array}{l}\text { Lawsonia } \\
\text { inermis }\end{array}$ & Daun & $\begin{array}{l}\text { Ditempel, } \\
\text { Dihalusakn }\end{array}$ & $\begin{array}{l}\text { Jamur kuku, } \\
\text { warnai } \\
\text { kuku, } \\
\text { kembung. }\end{array}$ & $\begin{array}{l}\text { Cacingan, demam, } \\
\text { mencret. } \\
\text { (Hariana, 2008: } \\
302 \text { ) }\end{array}$ \\
\hline $3 \mathrm{I}$ & Pecut kuda & Verbenaceae & $\begin{array}{l}\text { Stachytarpheta } \\
\text { jamaisensis }\end{array}$ & $\begin{array}{l}\text { Akar, } \\
\text { bunga, } \\
\text { daun }\end{array}$ & Diperas & Bisul. & $\begin{array}{l}\text { Rematik, } \\
\text { keputihan, } \\
\text { hepatitis. } \\
\text { (Hidayat \& } \\
\text { Napitupulu 20I5: } \\
\text { 3I0) }\end{array}$ \\
\hline 32 & $\begin{array}{l}\text { Petikan } \\
\text { kebo }\end{array}$ & Euphorbiaceae & Euphorbia hirta & $\begin{array}{l}\text { Seluruh } \\
\text { bagian }\end{array}$ & Direbus & $\begin{array}{l}\text { Sariawan, } \\
\text { disentri, } \\
\text { asma. }\end{array}$ & $\begin{array}{l}\text { Bronkhitis, radang } \\
\text { tenggorokan, } \\
\text { asma. (Hidayat \& } \\
\text { Napitupulu 20I5: } \\
308\end{array}$ \\
\hline 33 & Pinang & Palmae & Areca catechu & Biji & $\begin{array}{l}\text { Diasapkan } \\
\text { /Dipanggan } \\
\text { g, Ditempel }\end{array}$ & $\begin{array}{l}\text { Cacingan, } \\
\text { gatal-gatal. }\end{array}$ & $\begin{array}{l}\text { Cacingan. (Agung, } \\
\text { 2005:53) }\end{array}$ \\
\hline 34 & $\begin{array}{l}\text { Rambutan/ } \\
\text { Mutan }\end{array}$ & Sapindaceae & $\begin{array}{l}\text { Naphelium } \\
\text { lappaceum }\end{array}$ & $\begin{array}{l}\text { Kulit } \\
\text { buah, } \\
\text { daun, biji }\end{array}$ & $\begin{array}{l}\text { Tanpa } \\
\text { Diramu. } \\
\text { Direbus }\end{array}$ & $\begin{array}{l}\text { Disentri, } \\
\text { demam, } \\
\text { sariawan. }\end{array}$ & $\begin{array}{l}\text { Disentri, demam, } \\
\text { diare, kencinng } \\
\text { manis. (Hidayat \& } \\
\text { Napitupulu 20I5: } \\
\text { 329) }\end{array}$ \\
\hline 35 & $\begin{array}{l}\text { Sawo/ } \\
\text { Hawo }\end{array}$ & Sapotaceae & $\begin{array}{l}\text { Manilkara } \\
\text { zapota }\end{array}$ & $\begin{array}{l}\text { Buah, } \\
\text { getah }\end{array}$ & $\begin{array}{l}\text { Direbus, } \\
\text { Diparut, } \\
\text { Tanpa } \\
\text { Diramu, } \\
\text { Diperas, } \\
\text { Diseduh }\end{array}$ & $\begin{array}{l}\text { Disentri, } \\
\text { diare, } \\
\text { sariawan. }\end{array}$ & $\begin{array}{l}\text { Diare, disentri. } \\
\text { (Hidayat \& } \\
\text { Napitupulu 20I5: } \\
343 \text { ) }\end{array}$ \\
\hline 36 & Senduduk & Melastomataceae & $\begin{array}{l}\text { Melastoma } \\
\text { malabathricum }\end{array}$ & $\begin{array}{l}\text { Daun, } \\
\text { akar }\end{array}$ & $\begin{array}{l}\text { Direbus, } \\
\text { Dihaluskan }\end{array}$ & $\begin{array}{l}\text { Sakit gigi, } \\
\text { malaria, } \\
\text { disentri. }\end{array}$ & $\begin{array}{l}\text { Diare, disentri, } \\
\text { sakit gigi, luka, } \\
\text { penetral racun. } \\
\text { (Hidayat \& } \\
\text { Napitupulu 20I5: } \\
350 \text { ) }\end{array}$ \\
\hline 37 & Sirsak/ & Annonaceae & Anona muricata & Daun & Direbus & Kanker & Penurun darah \\
\hline
\end{tabular}




\begin{tabular}{|c|c|c|c|c|c|c|c|}
\hline & $\begin{array}{l}\text { Nake } \\
\text { belendo }\end{array}$ & & & & & & $\begin{array}{l}\text { tinggi (Hidayat \& } \\
\text { Napitupulu 20I5: } \\
367 \text { ) }\end{array}$ \\
\hline 38 & Tapak dara & Apacynaseae & $\begin{array}{l}\text { Catharantthus } \\
\text { roseus }\end{array}$ & Daun & Direbus & Kanker & $\begin{array}{l}\text { Asma, demam, } \\
\text { kencing manis, } \\
\text { bisul, disentri } \\
\text { (Sa'adah, 2007: } \\
66)\end{array}$ \\
\hline 49 & $\begin{array}{l}\text { Terong susu } \\
\text { kerbau }\end{array}$ & Solanaceae & $\begin{array}{l}\text { Solanum } \\
\text { mammosum }\end{array}$ & Biji & $\begin{array}{l}\text { Ditempel, } \\
\text { Diasapkan / } \\
\text { Dipanggang, } \\
\text { Diteteskan } \\
\end{array}$ & $\begin{array}{l}\text { Kanker } \\
\text { payudara }\end{array}$ & $\begin{array}{l}\text { Kecacingan } \\
\text { (Herawati, 2000: } \\
\text { IIO) }\end{array}$ \\
\hline 40 & $\begin{array}{l}\text { Ubi jalar/ } \\
\text { Kepar }\end{array}$ & Euphorbiaceae & Ipomea batatas & $\begin{array}{l}\text { Daun, } \\
\text { batang, } \\
\text { umbi. }\end{array}$ & $\begin{array}{l}\text { Direbus, } \\
\text { Dihaluskan }\end{array}$ & $\begin{array}{l}\text { Malaria, } \\
\text { demam } \\
\text { berdarah, } \\
\text { mabuk } \\
\text { perjalanan. }\end{array}$ & $\begin{array}{l}\text { (Hidayat \& } \\
\text { Napitupulu, } \\
\text { 2015: 397) }\end{array}$ \\
\hline
\end{tabular}

